Original Article

\title{
Chemical composition, in vitro larvicidal and antileishmanial activities of the essential oil from Citrus reticulata Blanco fruit peel
}

\author{
Composição química, atividades larvicida e leishmanicida in vitro do óleo essencial da \\ casca do fruto de Citrus reticulata Blanco
}

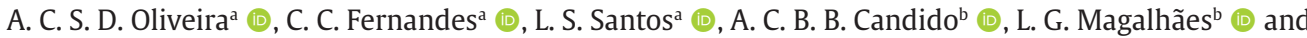 \\ M. L. D. Miranda ${ }^{* *}$ (D) \\ aInstituto Federal de Educação, Ciência e Tecnologia Goiano, Campus Rio Verde, Rio Verde, GO, Brasil \\ 'Universidade de Franca, Núcleo de Pesquisas em Ciências Exatas e Tecnológicas, Franca, SP, Brasil \\ Instituto Federal de Educação, Ciência e Tecnologia do Triângulo Mineiro, Campus Uberlândia Centro, Uberlândia, MG, Brasil
}

\begin{abstract}
Numerous studies have investigated the chemical composition and biological activities of essential oils from different Citrus species fruit peel, leaves and flowers. This paper aims to investigate the chemical composition, larvicidal and antileishmanial activities of essential oil from Citrus reticulata fruit peel (CR-EO). CR-EO was obtained by hydrodistillation in a Clevenger-type apparatus and its chemical composition was analyzed by GC-MS and GC-FID. Limonene (85.7\%), $\mathrm{\gamma}$-terpinene (6.7\%) and myrcene (2.1\%) were identified as its major components. CR-EO showed high activity against promastigote forms of Leishmania amazonensis $\left(\mathrm{IC}_{50}=8.23 \mu \mathrm{g} / \mathrm{mL}\right.$ ). CR-EO also exhibited high larvicidal activity against third instar Aedes aegypti larvae at a lethal concentration $\left(\mathrm{LC}_{50}=58.35 \mu \mathrm{g} / \mathrm{mL}\right)$ and $100 \%$ mortality at $150 \mu \mathrm{g} / \mathrm{mL}$. This study suggests, for the first time, the potential use of CR-EO against this important mosquito-borne viral disease caused by the genus Aedes.
\end{abstract}

Keywords: Leishmania amazonensis, Aedes aegypti, limonene.

\section{Resumo}

Numerosos estudos têm investigado a composição química e as atividades biológicas de óleos essenciais extraídos de cascas dos frutos, folhas e flores de diferentes espécies de Citrus. Este trabalho tem como objetivo investigar a composição química e as atividades larvicida e leishmanicida in vitro do óleo essencial das cascas dos frutos de Citrus reticulata (CR-EO). CR-EO foi obtido pela técnica de extração em aparelho Clevenger e sua composição química foi determinada por CG-EM e CG-DIC. Limoneno (85,7\%), $\gamma$-terpineno (6,7\%) and mirceno (2,1\%) foram identificados como os constituintes majoritários. CR-EO mostrou alta atividade contra as formas promastigota de Leishmania amazonensis $\left(\mathrm{Cl}_{50}=8,23 \mu \mathrm{g} / \mathrm{mL}\right)$. CR-EO também exibiu alta atividade larvicida contra as larvas do terceiro estágio do Aedes aegypti com concentração letal $\left(\mathrm{CL}_{50}=58,35 \mu \mathrm{g} / \mathrm{mL}\right)$ e mortalidade de $100 \% \mathrm{em} 150 \mu \mathrm{g} / \mathrm{mL}$. Este estudo sugere, pela primeira vez, o uso potencial de CR-EO contra esta importante doença viral transmitida por mosquitos do gênero Aedes.

Palavras-chave: Leishmania amazonensis, Aedes aegypti, limoneno.

\section{Introduction}

Concern for the control and fight against Aedes aegypti, the mosquito that is the main vector of a severe hemorrhagic disease known as dengue, has been latent (Wankhar et al., 2015). The number of dengue cases has reached about 400 million per year. In the last 50 years, this disease has been endemic in 128 countries, while 36 countries are considered dengue-free ones. The highest prevalences are found in countries in the Americas, Asia and Africa, i. e., 3.97 billion inhabitants are exposed to the risk of infection (Brady et al., 2012). In addition to the dengue virus, the vector may transmit other diseases known all over the world as chikungunya and zika (Neves et al., 2017).

Leishmaniasis is another worrisome disease worldwide which is also caused by the infected vector known as "straw mosquito" (Silva et al., 2020). The estimate is that 2 million new cases of leishmaniasis occur annually and that between 15 and 20 million people have got the disease in the world (Moreira et al., 2019). In the search for plants

*e-mail: maykermiranda@iftm.edu.br

Received: January 13, 2021 - Accepted: March 3, 2021 
with therapeutic potential, species of the genus Citrus not only have economic importance, but also produce bioactive essential oils (EOs) which have high value in perfume, food and beverage industries (Dosoky and Setzer, 2018).

EOs and extracts from Citrus reticulata fruit peel and leaves have several biological applications, such as antimicrobial, antioxidant, anti-inflammatory, anticancer, antiproliferative, anti-pulmonary fibrosis, hypoglycemic and insecticidal ones, besides being useful in skin care (Hamdan et al., 2016; Apraj and Pandita, 2016). Therefore, this study aimed to evaluate the chemical composition, larvicidal and anti-Leishmania amazonensis activities of essential oil from $C$. reticulata fruit peel (CR-EO). So far, larvicidal activity of CR-EO against third instar A. aegypti larvae has not been investigated in the literature.

\section{Material and Methods}

\subsection{Plant material}

Fruits were collected in Rio Verde (17 $99.4^{\prime} 63.2^{\prime \prime} \mathrm{S}$ and $\left.51^{\circ} 05.2^{\prime} 44.6^{\prime \prime} \mathrm{W}\right)$, a city located in Goiás state, Brazil, on January 18th, 2019, at 9 a.m. The plant was identified by the botanist Luzia Francisca de Souza and a voucher specimen of Citrus reticulata was deposited in the herbarium in Rio Verde, at the Instituto Federal Goiano (IFGOIANO) under identification number \#4488.

\subsection{Essential oil extraction}

Essential oil (EO) was extracted from C. reticulata (CR-EO) fruit peel by hydrodistillation for $3 \mathrm{~h}$ in a Clevenger-type apparatus. Hydrodistillation was performed in triplicate. To this end, fruit peel was divided into three $500-\mathrm{g}$ samples and $500 \mathrm{~mL}$ distilled water was added to each sample. After manual collection of EO, remaining traces of water were removed with anhydrous sodium sulfate. Filtration was then carried out. EO was stored in an amber bottle and kept in a refrigerator at $4{ }^{\circ} \mathrm{C}$ until analysis (Carneiro et al., 2017).

\subsection{Chemical identification of essential oil from C. reticulata fruit peel (CR-EO)}

CR-EO was dissolved in ethyl ether and analyzed by gas chromatography-flame ionization detection (GC-FID) and gas chromatography-mass spectrometry (GC-MS), with the use of Shimadzu QP5000 Plus and GCMS2010 Plus (Shimadzu Corporation, Kyoto, Japan) systems. The temperature of the column in GC-FID was programmed to rise from 60 to $240^{\circ} \mathrm{C}$ at $3^{\circ} \mathrm{C} / \mathrm{min}$ and was held at $240{ }^{\circ} \mathrm{C}$ for $5 \mathrm{~min}$; the carrier gas was $\mathrm{H}_{2}$ at a flow rate of $1.0 \mathrm{~mL} / \mathrm{min}$. The equipment was set to operate in the injection mode; the injection volume was $0.1 \mu \mathrm{L}$ (split ratio of $1: 10$ ), while injector and detector temperatures were 240 and $280^{\circ} \mathrm{C}$, respectively. Relative concentrations of components were obtained by normalizing peak areas (\%). Relative areas consisted of the average of triplicate GC-FID analyses. GC-MS conditions and the identification of essential oils have been previously reported (Lemes et al., 2018). Identification of volatile components of essential oil from $C$. reticulata (Table 1 ) was based on their retention
Table 1. Chemical composition of essential oil from Citrus reticulata fruit peel (CR-EO).

\begin{tabular}{ccccc}
\hline RTmin & Compounds & RI $_{\text {exp }}$ & RI $_{\text {lit }}$ & \%RA \\
\hline 6.28 & $\alpha$-Thujene & 852 & 851 & 0.2 \\
9.09 & $\alpha$-Pinene & 935 & 934 & 0.6 \\
10.78 & Sabinene & 975 & 974 & 0.5 \\
11.57 & Myrcene & 993 & 991 & $\mathbf{2 . 1}$ \\
13.82 & Limonene & 1039 & 1039 & $\mathbf{8 5 . 7}$ \\
14.32 & Trans- $\beta$-ocimene & 1051 & 1050 & 0.7 \\
14.81 & $\gamma$-terpinene & 1062 & 1062 & $\mathbf{6 . 7}$ \\
18.59 & Limonene oxide & 1132 & 1133 & 0.5 \\
19.31 & Citronellal & 1158 & 1158 & 0.1 \\
21.13 & $\alpha$-Terpineol & 1184 & 1185 & 0.1 \\
24.12 & Geraniol & 1254 & 1255 & 0.1 \\
24.86 & Geranial & 1271 & 1270 & 0.2 \\
37.92 & Caryophyllene oxide & 1581 & 1581 & 0.3 \\
& Total & & & 97.8 \\
\hline
\end{tabular}

RTmin: retention time; $\mathbf{R I}_{\text {exp }}$ : Retention index relative to $n$-alkanes $\left(C_{8}-C_{20}\right)$ on the Rtx-5MS column; $\mathbf{R I}_{\text {lit }}$ : Kovats retention index (values from literature - Adams, 2007); \%RA: Relative abundance.

indices on an Rtx-5MS (30 m × $0.25 \mathrm{~mm}$; $0.250 \mu \mathrm{m})$ capillary column under the operating conditions used for GC relative to a homologous series of $n$-alkanes $\left(C_{8}-C_{20}\right)$. Structures were computer-matched with Wiley 7, NIST 08 , and FFNSC 1.2, and their fragmentation patterns were compared with literature data (Adams, 2007).

\subsection{Larvicidal assay}

Larvae of A. aegypti were obtained from the Laboratório de Patologia Tropical e Saúde Pública that belongs to the Universidade Federal de Goiás, UFG, Brazil. The larvicidal assay was performed in agreement with a previously reported method (Mesquita et al., 2018), as follows: larvae were kept in plastic trays under controlled temperature $\left(26 \pm 2{ }^{\circ} \mathrm{C}\right)$ and humidity (70-80\%) until they reached the third final instar stage. Afterwards, 10 larvae were transferred to $50-\mathrm{mL}$ plastic cups, each containing $10 \mathrm{~mL}$ mineral water and ground fish food (TetraMin Tropical Flakes), followed by the addition of $100 \mu \mathrm{L}$ solution of CR-EO in dimethyl sulfoxide (DMSO) $(25-500 \mu \mathrm{g} / \mathrm{mL})$. After 24 hours, the number of dead larvae was counted and the lethal percentage was calculated. All experiments were carried out in quintuplicate, including a negative control treatment with DMSO, mineral water, larvae and ground fish food. Permethrin was used as a positive control. Larvicidal activities were reported as lethal concentration at $50 \%\left(\mathrm{LC}_{50}\right)$, representing the concentration in micrograms per milliliter that caused 50\% larval mortality, with 95\% confidence interval. Mortality data were assessed by probit analysis (Finney, 1971). Mortality data were treated by the Polo plus ${ }^{\circledR}$ software (Robertson et al., 2003) with 95\% confidence interval and values of $\mathrm{P}<0.05$ were considered statistically significant. 
Table 2. Antileishmanial activity of essential oil from Citrus reticulata fruit peel (CR-EO).

\begin{tabular}{ccccccc}
\hline & \multicolumn{5}{c}{ Concentrations $(\mu \mathrm{g} / \mathbf{m L}) \pm$ Standard deviation } \\
\cline { 2 - 7 } & $\mathbf{1 0 0}$ & $\mathbf{5 0}$ & $\mathbf{2 5}$ & $\mathbf{1 2 . 5}$ & $\mathbf{6 . 2 5}$ & $\mathbf{I C}_{\mathbf{5 0}}(\mu \mathrm{g} / \mathbf{m L})$ \\
\hline CR-EO & $100 \pm 0.00$ & $100 \pm 0.00$ & $64.86 \pm 5.98$ & $58.14 \pm 7.69$ & $47.92 \pm 4.86$ & $8.23 \pm 1.10$ \\
& $\mathbf{0 . 1 9}$ & $\mathbf{0 . 0 9 5}$ & $\mathbf{0 . 0 4 7}$ & $\mathbf{0 . 0 2 3}$ & $\mathbf{0 . 0 1 1}$ & \\
Amph. B & $44.38 \pm 0.53$ & $36.89 \pm 0.79$ & $33.61 \pm 0.62$ & $29.02 \pm 1.85$ & $23.50 \pm 1.58$ & $0.25 \pm 0.39$ \\
\hline
\end{tabular}

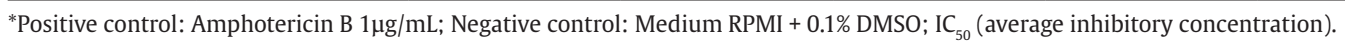

\subsection{Antileishmanial assay}

To evaluate antileishmanial activity, L. amazonensis promastigote forms (MHOM/BR/PH8) were maintained in RPMI 1640 (Gibco) culture medium supplemented with 10\% fetal bovine serum, penicillin ( $100 \mathrm{UI} / \mathrm{mL}$ ) and streptomycin $(100 \mu \mathrm{g} / \mathrm{mL})$. Subsequently, about $1 \times 10^{6}$ parasites were distributed on 96-well plates, while CR-EO previously dissolved in 100\% dimethylsulfoxide (DMSO, stock solution $100 \mathrm{mM}$ ) (Synth) was added to the cultures at concentrations of 6.25 to $100 \mu \mathrm{g} / \mathrm{mL}$. Amphotericin B (Sigma Aldrich, 97\% purity), at concentrations ranging from 0.011 to $0.19 \mu \mathrm{g} / \mathrm{mL}$, was added to cultures and used as positive control. Cultures were incubated in a BOD (Quimis) incubator at $25^{\circ} \mathrm{C}$ for $24 \mathrm{~h}$ and antileishmanial activity was determined by verifying whether growth of promastigote forms was inhibited. It was carried out by counting the total number of live promastigotes in the Neubauer (Global Glass - Porto Alegre, BR) chamber on the basis of flagellar motility. RPMI 1640 medium (Gibco) containing 0.1\% DMSO (Synth) (highest concentration) was used. Results were expressed as the average of the percentage of growth inhibition relative to the negative control (0.1\% DMSO) (Cabral et al., 2020).

\section{Results and Discussion}

Volatile compounds were identified by gas chromatography-flame ionization detection (GC-FID) and gas chromatography-mass spectrometry (GC-MS). Thirteen compounds, which represent $97.8 \%$ of all components, were identified in the oil from fruit peel. Major compounds found in CR-EO were limonene (85.7\%), $\gamma$-terpinene (6.7\%) and myrcene (2.1\%) (Table 1$)$.

Previous reports of EOs from fruit peel from other C. reticulata specimens showed that terpenes limonene, sabinene, linalool, $\mathrm{\gamma}$-terpinene, octanal and capraldehyde were its major constituents (Hamdan et al., 2016; Martins et al., 2017). EOs from different Citrus species are chemically similar with the predominance of the monoterpene limonene, characteristics that are pointed out by Bozkurt et al. (2017). High limonene concentration (74.38\%) was also identified in C. reticulata peel grown in Spain (Espina et al., 2011). A recent study of ten Citrus species should be highlighted, since it reinforces limonene and aldehyde compounds in CR-EO (González-Mas et al., 2019).

CR-EO had its larvicidal activity investigated against third instar A. aegypti larvae. Initially, larvae in contact with CR-EO showed accelerated movement. However, after prolonged exposure, they began to exhibit tremor and slow or lethargic movement, even when artificially stimulated. CR-EO also caused darkening of the entire larval body. Doses of $12.5,25,50 \mathrm{and} 100 \mu \mathrm{g} / \mathrm{mL}$ resulted in 10.2, 25.1, 51.7 and $85.3 \%$ of dead larvae, respectively, while $150 \mu \mathrm{g} / \mathrm{mL}$ ensured $100 \%$ mortality. LC $_{50}$ of CR-EO was $58.35 \mu \mathrm{g} / \mathrm{mL}$. Even though EOs from several Citrus species have already been tested against $A$. aegypti larvae, this is the first promising report of $C$. reticulata. Larvicidal and insecticidal activities have already been evaluated in EOs from C. sinensis, C. limon, C. grandis, C. aurantifolia, C. hystrix, C. maxima and C. medica (Araújo et al., 2016; Gomes et al., 2019; Sarma et al., 2017, 2019; Soonwera, 2015). High larvicidal activity could be due to the high limonene concentration (85.7\%), a botanical insecticide which has been patented as an active agent of larvicidal formulations (Dias and Moraes, 2014).

Regarding antileishmanial activity, CR-EO was promising against promastigote forms of $L$. amazonensis $\left(\mathrm{IC}_{50}=8.23 \mu \mathrm{g} / \mathrm{mL}\right)$ (Table 2).

Several authors have reported that EOs whose values are $\mathrm{IC}_{50}<10 \mu \mathrm{g} / \mathrm{mL}$ are highly active (Silva et al., 2020; Almeida et al., 2020). The range of $\mathrm{IC}_{50}$ values that considers EOs highly active has been described by Estevam et al. (2016), who studied EOs from C. limonia and C. latifolia fresh leaves. It should be highlighted that results found by the study reported by this paper do not agree with the ones reported by Monzote et al. (2019), since the $\mathrm{IC}_{50}$ value of commercially obtained CR-EO was $70.7 \mu \mathrm{g} / \mathrm{mL}$. This fact leads to questioning the nature of EOs that are commercialized with no compliance with regulations. On the other hand, high antileishmanial activity of CR-EO found by this study may also be justified by the amount of limonene, a monoterpene that exhibits this activity against parasites that belong to the genus Leishmania (Arruda et al., 2009).

\section{Conclusion}

This study described the chemical composition of CR-EO, in which thirteen compounds were identified, and showed their high larvicidal activity against Aedes aegypti larvae and anti-Leishmania amazonensis promastigote forms. Limonene, as the major compound in CR-EO, could explain their high larvicidal and antileishmanial activities. This communication is the first report of larvicidal evaluation of CR-EO. 


\section{Acknowledgements}

The authors are grateful to FAPEG, CNPq, CAPES and IF GOIANO - Campus Rio Verde for their financial support.

\section{References}

ADAMS, R.P., 2007. Identification of essential oil components by gas chromatography/quadrupole mass spectroscopy. 4th ed. Carol Stream: Allured Publishing Corporation, $804 \mathrm{p}$.

ALMEIDA, K.C.R., SILVA, B.B., ALVES, C.C.F., VIEIRA, T.M., CROTTI, A.E.M., SOUZA, J.M., MARTINS, C.H.G., RIBEIRO, A.B., SQUARISI, I.S., TAVARES, D.C., BERNABÉ, L.S., MAGALHÃES, L.G. and MIRANDA, M.L.D., 2020. Biological properties and chemical composition of essential oil from Nectandra megapotamica (Spreng.) Mez. leaves (Lauraceae). Natural Product Research, vol. 34, no. 21, pp. 3149-3153. http://dx.doi.org/10.1080/1478 6419.2019.1608539. PMid:31084218.

APRAJ, V.D. and PANDITA, N.S., 2016. Evaluation of skin anti-aging potential of Citrus reticulata blanco peel. Pharmacognosy Research, vol. 8, no. 3, pp. 160-168. http://dx.doi.org/10.4103/09748490.182913. PMid:27365982.

ARAÚJO, A.F.O., RIBEIRO-PAES, J.T., DEUS, J.T., CAVALCANTI, S.C.H., NUNES, R.S., ALVES, P.B. and MACORIS, M.L.G., 2016. Larvicidal activity of Syzygium aromaticum (L.) Merr and Citrus sinensis (L.) Osbeck essential oil and their antagonistic effects with temephos in resistant populations of Aedes aegypti. Memórias do Instituto Oswaldo Cruz, vol. 111, no. 7, pp. 443-449. http:// dx.doi.org/10.1590/0074-02760160075. PMid:27384083.

ARRUDA, D.C., MIGUEL, D.C., YOKOYAMA-YASUNAKA, J.K.U., KATZIN, A.M. and ULIANA, S.R.B., 2009. Inhibitory activity of limonene against Leishmania parasites in vitro and in vivo. Biomedicine and Pharmacotherapy, vol. 63, no. 9, pp. 643-649. http://dx.doi. org/10.1016/j.biopha.2009.02.004. PMid:19321295.

BOZKURT, T., GULNAZ, O. and KAÇAR, Y.A., 2017. Chemical composition of the essential oils from some citrus species and evaluation of the antimicrobial activity. Journal of Environmental Science. Toxicology and Food Technology, vol. 11, pp. 29-33. http://dx.doi.org/10.9790/2402-1110032933.

BRADY, O.J., GETHING, P.W., BHATT, S., MESSINA, J.P., BROWNSTEIN, J.S., HOEN, A.G., MOYES, C.L., FARLOW, A.W., SCOTT, T.W. and HAY, S.I., 2012. Refining the global spatial limits of dengue virus transmission by evidence-based consensus. PLoS Neglected Tropical Diseases, vol. 6, no. 8, e1760. http://dx.doi.org/10.1371/ journal.pntd.0001760. PMid:22880140.

CABRAL, F.D., FERNANDES, C.C., RIBEIRO, A.B., SQUARISI, I.S., TAVARES, D.C., CANDIDO, A.C.B.B., MAGALHÃES, L.G., SOUZA, J.M., MARTINS, C.H.G. and MIRANDA, M.L.D., 2020. Bioactivities of essential oils from different parts of Spiranthera odoratissima (Rutaceae). Rodriguésia, vol. 71, e00902019. http://dx.doi. org/10.1590/2175-7860202071050.

CARNEIRO, N.S., ALVES, J.M., ALVES, C.C.F., ESPERANDIM, V.R. and MIRANDA, M.L.D., 2017. Óleo essencial das flores de Eugenia klotzschiana (Myrtaceae): composição química e atividades tripanocida e citotóxica in vitro. Revista Virtual de Química, vol. 9, no. 3, pp. 1381-1392. http://dx.doi.org/10.21577/19846835.20170080 .

DIAS, C.N. and MORAES, D.F.C., 2014. Essential oils and their compounds as Aedes aegypti L. (Diptera: Culicidae) larvicides. Parasitology Research, vol. 113, no. 2, pp. 565-592. http://dx.doi. org/10.1007/s00436-013-3687-6. PMid:24265058.

DOSOKY, N.S. and SETZER, W.N., 2018. Biological activities and safety of Citrus spp. Essential oils. International Journal of Molecular
Sciences, vol. 19, no. 7, pp. 1966. http://dx.doi.org/10.3390/ ijms19071966. PMid:29976894.

ESPINA, L., SOMOLINOS, M., LORÁN, S., CONCHELLO, P., GARCÍA, D. and PAGÁN, R., 2011. Chemical composition of commercial citrus fruit essential oils and evaluation of their antimicrobial activity acting alone or in combined process. Food Control, vol. 22, no. 6, pp. 896-902. http://dx.doi.org/10.1016/j.foodcont.2010.11.021.

ESTEVAM, E.B.B., MIRANDA, M.L.D., ALVES, J.M., EGEA, M.B., PEREIRA, P.S., MARTINS, C.H.G., ESPERANDIM, V.R., MAGALHÃES, L.G., BOLELA, A.C., CAZAL, C.M., SOUZA, A.F. and ALVES, C.C.F., 2016. Composição química e atividades biológicas dos óleos essenciais das folhas frescas de Citrus limonia Osbeck e Citrus latifolia Tanaka (Rutaceae). Revista Virtual de Química, vol. 8, pp. 1842-1854. http://dx.doi.org/10.21577/1984-6835.20160124.

FINNEY, D.J., 1971. Probit analysis. Cambridge: Cambridge University Press.

GOMES, P.R.B., OLIVEIRA, M.B., SOUSA, D.A., SILVA, J.C., FERNANDES, R.P., LOUZEIRO, H.C., OLIVEIRA, R.W.S., PAULA, M.L., FILHO, V.E.M. and FONTENELE, M.A., 2019. Larvicidal activity, molluscicide and toxicity of the essential oil of Citrus limon peels against, respectively, Aedes aegypti, Biomphalaria glabrata and Artemia salina. Eclética Química Journal, vol. 44, no. 4, pp. 85-95. http:// dx.doi.org/10.26850/1678-4618eqj.v44.4.2019.p85-95.

GONZÁLEZ-MAS, M.C., RAMBLA, J.L., LÓPEZ-GRESA, M.P., BLÁZQUEZ, M.A. and GRANELL, A., 2019. Volatile compounds in Citrus essential oils: a comprehensive review. Frontiers in Plant Science, vol. 10, pp. 12. http://dx.doi.org/10.3389/fpls.2019.00012. PMid:30804951.

HAMDAN, D.I., MOHAMED, M.E. and EL-SHAZLY, A.M., 2016. Citrus reticulata Blanco cv. Santra leaf and fruit peel: a common waste products, volatile oils composition and biological activities. Journal of Medicinal Plants Research, vol. 10, no. 30, pp. 457-467. http://dx.doi.org/10.5897/JMPR2016.6139.

LEMES, R.S., ALVES, C.C.F., ESTEVAM, E.B.B., SANTIAGO, M.B., MARTINS, C.H.G., SANTOS, T.C.L., CROTTI, A.E.M. and MIRANDA, M.L.D., 2018. Chemical composition and antibacterial activity of essential oils from Citrus aurantifolia leaves and fruit peel against oral pathogenic bacteria. Anais da Academia Brasileira de Ciências, vol. 90, no. 2, pp. 1285-1292. http://dx.doi.org/10.1590/00013765201820170847. PMid:29898096.

MARTINS, M.H.G., FRACAROLLI, L., VIEIRA, T.M., DIAS, H.J., CRUZ, M.G., DEUS, C.C.H., NICOLELLA, H.D., STEFANI, R., RODRIGUES, V., TAVARES, D.C., MAGALHÃES, L.G. and CROTTI, A.E.M., 2017. Schistosomicidal effects of the essential oils of Citrus limonia and Citrus reticulata against Schistosoma mansoni. Chemistry E' Biodiversity, vol. 14, no. 1, pp. e1600194. http://dx.doi. org/10.1002/cbdv.201600194. PMid:27936310.

MESQUITA, R.S., TADEI, W.P., BASTOS and A.M.B., 2018. Determination of the larvicidal activity of benzoyl thiosemicarbazone and its $\mathrm{Ni}(\mathrm{II})$ complex against Aedes aegypti and Anopheles darlingi larvae in Amazonas, Brazil.Journal of Entomology and Nematology, vol. 10, no. 6, pp. 37-42. https://doi.org/10.5897/JEN2018.0207.

MONZOTE, L., HERRERA, I., SATYAL, P. and SETZER, W.N., 2019. In-vitro evaluation of 52 commercially-available essential oils against Leishmania amazonensis. Molecules, vol. 24, no. 7, pp. 1248. http://dx.doi.org/10.3390/molecules24071248. PMid:30934998.

MOREIRA, R.R.D., SANTOS, A.G., CARVALHO, F.A., PEREGO, C.H., CREVELIN, E.J., CROTTI, A.E.M., COGO, J., CARDOSO, M.L.C. and NAKAMURA, C.V., 2019. Antileishmanial activity of Melampodium divaricatum and Casearia sylvestris essential oils on Leishmania amazonensis. Revista do Instituto de Medicina Tropical de São Paulo, vol. 61, pp. e33. http://dx.doi.org/10.1590/s16789946201961033. PMid:31269109. 
NEVES, I.A., REZENDE, S.R.F., KIRK, J.M., PONTES, E.G. and CARVALHO, M.G., 2017. Composition and larvicidal activity of essential oil of Eugenia candolleana DC. (Myrtaceae) against Aedes aegypti. Revista Virtual de Química, vol. 9, no. 6, pp. 2305-2315. http:// dx.doi.org/10.21577/1984-6835.20170138.

ROBERTSON, J.L., PREISLER, H.K. and RUSSELL, R.M., 2003. Poloplus probit and logit analysis. Berkeley: Leora Software, pp. 1-36.

SARMA, R., ADHIKARI, K., MAHANTA, S. and KHANIKOR, B., 2019. Insecticidal activities of Citrus aurantifolia essential oil against Aedes aegypti (Diptera: culicidae). Toxicology Reports, vol. 6, pp. 1091-1096. http://dx.doi.org/10.1016/j.toxrep.2019.10.009. PMid:31687359.

SARMA, R., KHANIKOR, B. and MAHANTA, S., 2017. Essential oil from Citrus grandis (Sapindales: Rutaceae) as insecticide against Aedes aegypti (L) (Diptera: Culicidae). Intertnational Journal of Mosquito Research, vol. 4, pp. 88-92.
SILVA, F.F.A., FERNANDES, C.C., OLIVEIRA, G.A., CANDIDO, A.C.B.B., MAGALHÃES, L.G., VIEIRA, T.M., CROTTI, A.E.M., SILVA, C.A. and MIRANDA, M.L.D., 2020. In vitro antileishmanial and antioxidant activities of essential oils from different parts of Murraya paniculata (L.) Jack: a species of Rutaceae that occur in the Cerrado bioma in Brazil. Australian Journal of Crop Science, vol. 14, no. 2, pp. 347-353. http://dx.doi.org/10.21475/ ajcs.20.14.02.p1966.

SOONWERA, M., 2015. Efficacy of essential oils from Citrus plantas against mosquito vectors Aedes aegypti (Linn.) and Culex quinquefasciatus (Say). Agricultural Technology, vol. 11, pp. 669-681.

WANKHAR, W., SRINIVASAN, S. and RATHINASAMY, S., 2015. HPTLC analysis of Scoparia dulcis Linn (Scrophulariaceae) and its larvicidal potential against dengue vector Aedes aegypti. Natural Product Research, vol. 29, no. 18, pp. 1757-1760. http:// dx.doi.org/10.1080/14786419.2014.999060. PMid:25573588. 